\title{
Determinants of Mortgage Price Affordability: A Study of Ghana
}

\section{ABSTRACT}

Purpose: While mortgage markets have gradually emerged in many African countries, substantial barriers still hinder their growth and expansion. Affordability has been widely cited as a prominent issue that doggedly remains at the core of urban housing problems. Hence, this research seeks to investigate the determinants of mortgage price affordability.

Design/methodology/approach: Data was gathered using semi-structured questionnaires obtained from a sample drawn from three major West African mortgage financing institutions. Respondents rated the variables using a fivepoint Likert item rating. The survey results were analysed using exploratory factor analysis.

Findings: Eleven variables that influence mortgage affordability were categorised within five principal components, namely: economic factors, financial factors, property characteristics, developmental factors and geographical factors.

Practical/ social implications: The results provide insightful guidance to policy makers and practitioners on how to mitigate affordability issues within Ghana's fledgling mortgage market. Failure to address the mortgage price affordability conundrum will place enormous pressure upon social housing and rental accommodation.

Originality/value: The research findings expand existing frontiers of knowledge by investigating and reporting upon the determinants of mortgage price affordability. The work also engenders wider debate on the need to establish mortgages packages targeted at low-middle income earners. The culmination of analysis and debate will provide a robust basis for developing a future housing policy framework.

KEYWORDS: Affordability, Financing, Ghana, Housing, Mortgage, Price

\section{INTRODUCTION}

Urbanization within Sub-Saharan Africa is on the rise and expected to increase exponentially in the coming decades and Ghana's urbanisation rate of $3.5 \%$ remains one of the highest in the world (UNFPA, 2007). This anticipated growth poses major infrastructure challenges including the housing deficit (Tarver, 1994). Sprawling urbanisation places enormous pressure on social housing, rental accommodation and the development of new affordable homes, resulting in rising cost and constrained 'affordability' as demand outstrips supply (Asabere et al., 2016) - where, affordability can be defined as accessibility to mortgage funds at an affordable financial repayment rate (i.e. lower interest rate mortgages). Ghana's current housing deficit is estimated to be circa 1.6 million homes and could double within ten years (Awuvafoge, 2013). Yartey (2012) recommends that to tackle this problem, an annual delivery of 150,000 units is required in lieu of the current paltry supply of 30,000 to 40,000 units per annum. Whilst this estimation (Yartey, 2012) is useful in terms of defining the magnitude of the 
problem, it fails to emphasise that a major root cause is the underdeveloped mortgage market (Asabereet al., 2016). Mortgage arrangements represent an effective means of generating housing funds for borrowers because they channel funds from those with surplus supply funds to those with deficit supply funds (Calomiriset al., 1994; Lea, 2000). However, Ghana's mortgage market is comparatively underdeveloped despite successive Ghanaian governments' attempts to employ ad-hoc housing initiatives without any comprehensive housing policy (Bonsu, 2007). For instance, Ghana's Mortgages Decree introduced in 1973 removed the mortgagees' right of sale and foreclosure without reference to the courts. This propagated self-financed housing mechanisms (SHM) such as incremental financing and capital financing which today accounts for circa $80 \%$ of new housing developments in Ghana.

However, the social equity gap between poor people living in formal and informal housing finance sectors has widened notably. Wolswijk (2005) proffers that a higher real disposable income per person increases the affordability of houses and that increased competition reduces the cost of credit to consumers (Lea, 1994). Similarly, Boamah (2003) argues that improved regulation coupled with increased competition between intermediaries will reduce the size of down payment requirement. According to Nwuba et al., (2015), previous studies conducted in the UK (Barker, 2004), New Zealand (Hargreaves, 2003), the USA (Gyourko and Linneman, 1993) and Nigeria (Chatterjee, 1982); demonstrate that affordability constraints have increasingly limited access to homeownership and have created a cavernous gap between aspirations for homeownership and its actualisation. To readdress this imbalance, Ghana's government has attempted to create an enabling economic environment via the formation of the House Finance Company (presently, HFC Bank), to provide mortgage funds to borrowers. However, the establishment of formal finance institutions has provided limited mortgage opportunities particularly for low-to-middle income households. For instance, total mortgages issued by the Home Finance Company in 2001 was US $\$ 4.9$ million which constituted approximately $95 \%$ of all mortgages created in Ghana that year (HFC, 2004). Mitlin (2008) observes that the introduction of micro-financing in the housing sector offers a promising potential solution for both housing and infrastructure development in low-income areas. Banks and specialized financial institutions have launched new programmes such as lower-income mortgages as a means of increasing home ownership in Ghana (ADB, 2011).

Yet, according to Asabere et al., (2016), while mortgage markets are gradually emerging in many African countries, substantial barriers still hinder their growth and expansion. For instance, in South Africa the mortgage financing market for low-income housing collapsed in 1994. However, to address housing needs of the low income sector, the South African government set up an innovative financing method to serve as motivation for mortgage lenders to provide loans to low income earners. The Government then injected funds to subsidize the housing cost of low income earners in the various provinces. The payment of the subsidy was made via the Provincial Housing Boards (PHBs). However in the year 2000, the government dissolved the structures of PHBs and made the Provincial Member of The Executive Council in- charge of the subsidy allocation. Between 1995 and 2001, one million subsidies were allocated - the 
majority to people earning less than South African Rand 1,500 (ZAR1,500) per month; about 8 per cent to people earning ZAR1,501-ZAR2,500 per month; and only 2 per cent of the subsidy was allocated to those earning less than ZAR3,500 per month (CSIR, 2000; South Africa National Department of Housing, 2001; Huchzermeyer, 2001; Pillay and Naude, 2006; Tomlinson, 2007) cited in (Ganiyu et al., (2017).

Affordability remains a prominent and persistent issue (Nwuba et al., 2015) as evidenced by various investigations that have explored the effectiveness of mortgage financing on housing provision (Boamah, 2009; UN Habitat, 2009). According to Nwuba et al., (2015), effective handling of homeownership issues requires an in-depth understanding of the determinants of affordability. Unfortunately, there is a dearth of extant literature regarding mortgage pricing affordability to meet low-to-middle income stipendiary; an important segment of any nation because this group forms the majority of a population. The principal ambition of this research therefore is to identify the determinants of mortgage price affordability (i.e. lower interest rate mortgages) in Ghana. In turn, this would provide stakeholders of housing and mortgage finance with ample information and tools to provide low interest rate mortgages to low income earners throughout Ghanaian society. Subsidiary aims are to engender wider debate on the need to establish mortgages packages targeted at low-middle income earners and contribute towards the development of a rigorous and robust housing policy framework for developing nations.

\section{GHANA'S HOUSING FINANCE AND MORTGAGE MARKET}

The most significant feature of home ownership in Ghana is that households generally prefer to build vis-a-vis buy homes. Hence, it is common practice for individuals to buy land(s), engage draughtsmen and skilled artisans and construct their homes over time - depending upon their income and savings. According to Nwuba et al., (2015), this approach remains popular because of the limited capacity/ inefficiency of the formal housing finance sector and the historical failure of housing programmes. Even today, access to formal mortgage financing largely remains elusive. McDonald and Thornton (2008) define a mortgage as a loan for real estate - a mortgage can therefore be both the instrument and process that pledges real estate as a security for an obligation. Popular categories of mortgage are: i) fixed rate - where the creditor/ investor assumes the interest risk while there is typically no prepayment penalty for the borrower; ii) adjustable rate - where the interest rate is periodically adjusted based on an index which reflects the cost of the lender's borrowing on the credit market (Posey and Yavas (2001); and iii) hybrid rate - which blends the characteristics of both the fixed and adjustable rate mortgages (Pennington and Ho, 2010).

The Ghanaian mortgage market traces its origin back to the First Ghana Building Society (FGBS) in 1956 under the Building Society Ordinance, 1955 (Act 30) and the Mortgages Decree, 1972 (NRCD 96) (Donkor-Hyiaman, 2013). This coincides with the pre-financial liberalization (1957-1987) and housing policy eras (1959-1964), when mortgage lending by the FGBS was financed largely by short-term deposits and direct government soft loans (Donkor-Hyiaman, 2013). In order for the government to perform its role as a facilitator and regulator 
under the 1970-1971 housing policy, the defunct Bank for Housing and Construction (BHC) was established to provide concessionary construction finance and credit to homebuyers (Donkor-Hyiaman, 2013). The mortgage market itself is currently characterised by: high liquidity risk; high and unstable interests rates; long-term maturities (about 30 years); and absence of a formal market to trade them (Boamah, 2009). Mortgage lenders in Ghana are unable to rapidly convert their mortgage assets to cash. However, depositors mostly prefer to convert deposits to cash to meet their respective demand for funds. Boamah (2009) attributes this to imbalances between the maturity of assets and liabilities of lenders consequently; the interest rate risk increases the likelihood of borrowers' default (Jaffe and Renaud, 1996). Major players within the market are HFC Bank, Ghana Home Loans (GHL), Fidelity Bank, CalBank (CalMortgage) and Stanbic Bank. These banks offer a variety of mortgage products, including mortgages for home purchase, improvement or completion, as well as home equity mortgages. Mortgage debt to GDP ratio has reduced in recent years from $0.37 \%, 0.42 \%, 0.3 \%$ and $0.25 \%$ in $2007,2008,2009$ and 2010 respectively, in part due to the global financial crisis and the prevalence of borrowers from the diaspora in Ghana's mortgage book. The shrink in mortgage debt to GDP ratio from 0.37 to 0.25 over this same four year period, shows the weak nature of the Ghanaian mortgage market. The Centre for Affordable Housing Finance (CAHF) (2012) indicate that, the cost of borrowing has reduced in Ghana, though this is dependent on the denomination of the loan. HFC Bank offers US Dollardenominated mortgages at a rate of $13.5 \%$, while mortgages in Ghana Cedis are offered at a $28 \%$ high (CAHF, 2012). Unfortunately, only about 3 percent of households can afford the cheapest formal sector dwelling on the market (CAHF,2012)

According to Donkor-Hyiaman (2013), within an average maximum term of 20 years, current mortgage rates of Ghana cedi-denominated and US dollardenominated mortgages averaged $30 \%$ and $13 \%$ (fixed) respectively. The mortgage portfolios of the two major players, Ghana Home Loans and HFC Bank stood at US\$65 million and US\$ 7.57 million in 2011 respectively, contributing to mortgage-to-GDP ratio of about $0.5 \%$ which is poor in comparison to the UK and USA at $85 \%$ and $77 \%$ respectively. Boamah (2009) argues that, the formal finance institutions established have provided very little mortgages particularly to the low-to-middle income households. Table 1 illustrates shows the volume of mortgage issued between 1992 and 2007.

\section{$<$ Insert Table 1 about here $>$}

Mortgages initiated in Ghana by the leading housing financier HFC during 1992 2007 does not present a positive outlook for the Ghanaian mortgage market. Mortgages from the HFC constitute a substantial share of the annual mortgages created in Ghana. For instance, the total mortgage from the HFC in 2001 was US $\$ 4.9$ million which was $95 \%$ of all mortgages created. Notwithstanding, the formal financial institutions allocated $15.9 \%$ of their total credit to miscellaneous sectors which include mortgages issued in 2007 (Budget Statement, 2008). This reflects how less important the formal finance institutions view mortgage finance as an investment opportunity. 


\section{HOUSING AFFORDABILITY}

The extant literature is replete with debate amongst scholars who cannot reach consensus on a universal definition and measurement of affordability (Poon and Garratt, 2012). Duan (2011) notes that the term of 'housing affordability' is ubiquitous amongst studies that examine housing purchase difficulties in various nations worldwide. Stone (2006) advocates the adoption of the residual income concept to measure housing affordability. Residual income represents a more accurate approach to measure affordability because it identifies the amount of disposable income after paying off monthly mortgage. It demonstrates the capacity of local households to purchase or rent housing and relates to an ecliptic assortment of considerations such as: the distribution of housing prices; housing quality and income; the ability of households to borrow; public policies affecting housing markets; and conditions affecting the supply of new or refurbished housing (Duan, 2011). Residual income describes housing that assists low-tomiddle income households in obtaining and paying for appropriate housing without experiencing undue financial hardship. The terminology 'affordable mortgage' is often used interchangeably to represent 'public', 'social' or 'low cost' housing (Gabriel et al., 2005). It is concerned with securing available financing schemes that assist lower income households in obtaining and paying for appropriate housing without experiencing undue financial hardship (Milligan et al., 2004; Maclennan and Williams, 1990). According to Nwuba et al. (2015), the concept of affordable housing can be viewed under three key dimensions, namely: i) affordability for renters; ii) affordability for existing homeowners; and iii) affordability for would-be homeowners.

The idea of affordable housing recognizes the needs of households within the lowto-middle income bracket whose income may not be sufficient to allow them to access appropriate housing in the market without assistance (Milligan et al., 2004). Widely used indicators of affordability for an individual, compare house prices relative to income or earnings or from a policy perspective, the ratio of lower quartile house prices to lower quartile earnings (Poon and Garratt, 2012). The African Development Bank (ADB) describes the middle class as households with annual income exceeding $\$ 3,900$ (GHs11, 700) in purchasing power parity. The middle class is also defined by the bank in relative terms, as individuals and households that fall between the 20th and 80th percentile of the consumption distribution. The ADB identifies three categories of middle class, namely: i) the floating class;ii) lower middle class; and iii) upper middle class. The floating class is unstably close to the poor with a per capita consumption of between $\$ 2$ (US Dollars) and $\$ 4$ per day. The per capita consumption of the lower-middle class and upper middle class is between $\$ 4-\$ 10$ per day and $\$ 10-\$ 20$ per day respectively. The ADB projects that by 2030 , countries such as Nigeria, Ethiopia and South Africa will produce the largest share of middle-class in Africa. It thus becomes important that to sustain a continued rise in Ghana's middle class will require the introduction of policies that sustain the incomes of those already in the middle class. Housing is one such policy, as it has the capacity to accelerate the reduction of poverty and improve habitable 'living' conditions.

The UN-Habitat (2009), outlines three important dimensions of poverty, namely: i) poverty of money; ii) poverty of access; and iii) poverty of power. Therefore those without money are ascribed to be poor and are effectively excluded from 
access to housing or exert political power to influence decisions about their welfare. Turner (1967) elucidated upon a nihilistic dystopian future where lowincome households in developing countries can only find shelter in squatter settlements. Yet, Ghana has witnessed a significant decrease of houses constructed with mud (49\%) to sandcrete bricks and concrete (Solomon-Ayeh, 1994) over the past 40 years. UNCHS (1996) argue that low-income households spend a greater proportion of their income on housing than upper-income households and that the low-income groups have diversity of demand for housing. The Ghana Statistical Service (2007) estimates the lower poverty line at GH $\phi$ 288.47 per adult per year and upper poverty is $\mathrm{GH} \phi 370.89$ per adult per year. Individuals whose consumption levels are above the upper poverty line are classified as non-poor. Baker (2004) states that the urban poor face various deprivations including: limited access to income and employment; inadequate and insecure living conditions; poor infrastructure and services; vulnerability to risks such as natural disasters, environmental hazards and health risks; spatial issues which inhibit mobility and transport; and social inequality.

While affordability is an easy concept to comprehend it remains difficult to execute in practice, especially given the changing circumstances of individuals and households over time (Bramley, 2012). To assess the extent of variability between places or household types and/or assessing changing circumstances over time, a benchmark average or percentile levels of incomes and costs are used (Paris, 2007). According to Poon and Garratt (2012), a popular indicator of affordability measures house prices relative to income or earnings. This permits the comparison of affordability across different regions (Barker, 2004). Critics of the affordable system of housing argue that $30 \%$ of a low income may be less 'affordable' than $40 \%$ of a high income because $60 \%$ out of a high income still leaves the household with an above-average disposable income (Paris 2007). While Battellino (2008) contends that the rise in real incomes since the early 1990s has substantially changed the basis upon which the $30 \%$ benchmark was originally proposed; affordability based on a percentage of a person's income is therefore insufficient. Cumulatively, the extant literature suggests that while mortgage financing has the propensity to address housing problem, a number of underlining factors prevail to nullify its potential impact, such as low income, high inflation rate and a poor regulatory framework (Asare and Whitehead, 2006; Boamah 2009; UN Habitat, 2009).

\section{MORTGAGE PRICING DETERMINANTS}

The major factors that affect the price of mortgages, and thus mortgage supply are inflation and exchange rate instability (Bank of Ghana 2007). Anticipated inflation affects the nominal interest rate charged, leading to high quoted repayments and thus the front-loading of payments to compensate for loss in purchasing power over time. Even where inflation is unanticipated in a risky environment, real interest rates may still increase due to high-risk premium (Bank of Ghana, 2007). Additionally, the uncertainty created by the persistent instability of a currency due to unstable inflation hinders access to external longterm finance for mortgage lending. The availability of potential mortgagors in a country also affects the pricing of a mortgage (Bank of Ghana, 2007). Low incomes levels manifest as high mortgage payment-to-income ratio for many loan applicants, thus pricing them out of the market. Additionally, estate developers 
quote prices in foreign exchange primarily as a hedge against currency depreciation which serves as a disincentive to demand for mortgage. Since mortgagors are required to make payments in local currencies, this often engenders higher costs of repayment (Bank of Ghana, 2007). Research carried out by Wang and Chen (2007) indicated that, mortgage price is determined by the following factors: loan-to-value (LTV), treasury rate, maturity of loan, characteristics of the mortgages and characteristics of the prevailing mortgage market. Empirical research by Owusu-Manu et al., (2016) used secondary data obtained from the Central Bank of Ghana which comprises of past macroeconomic independent variables such as real inflation rates, treasury bill rates and mortgage rates obtained from Home Finance Company (HFC) Bank. This research (Owusu-Manu et al., 2016), revealed that risk premium, inflation premium and real risk-free rate were key determinants of mortgage pricing in Ghana. However, the research was inconclusive as other important factors such as loan-to-value, maturity of mortgage loan, location of the property etc. were omitted. Hence, the justification for this present research. The pricing of mortgages and provision of housing should not be left solely to private companies since most of the mortgage pricing variables were expected to be influence by the performance of the economy which is under the remit of the government. Figure 1 and Figure 2 depict trend of inflation and interest rate respectively in Ghana

\section{$<$ Insert Figure 1 and Figure 2 about here $>$}

\section{RESEARCH METHODS}

A mixed method approach was adopted to explore how to create an efficient market that meets the affordability for both low and middle income bracket for the mortgage market in Ghana. Questionnaires and structured interviews were used to solicit primary data from HFC, GHL and Fidelity Bank on factors that determine the pricing of affordable mortgage on the mortgage market of Ghana. These three institutions have extensive experience and established track history of providing mortgage finance for low-middle income groups in Ghana. The review of extant literature and structured interview served as the basis for designing the questionnaire to assess pricing affordability in Ghana. The questionnaire included questions on potential determinant factors of mortgage pricing affordability including: i) base rate; ii) exchange rate; iii) treasury bill rate; iv) loan- to-value rate; v) lack of long term funds; vi) age of property; vii) property amount; viii) location of building; ix) property size; $\mathrm{x}$ ) poor infrastructure; xi) low income; xii) cost of building the property; and xiii)an underdeveloped mortgage market. Credit management personnel were targeted as respondents; and were made up of 25 personnel from the three mortgage finance institutions. The sample population comprises of eleven personnel from HFC bank, six from Fidelity bank and eight GHL.A sample size based on Kish's (1965) formula resulted in a sample size of 20 credit management personnel. The personnel were drawn disproportionately, nine personnel were selected from HFC Bank, five from Fidelity Bank and six from GHL using a simple random sampling technique to constitute the study sample. The respondents were invited to rate established factors influencing mortgage price affordability based on a Likert item of 0 (not important) to 4 (very important). 
The research adopted factor analysis to analyse the factors that influence mortgage price affordability in Ghana. Factor analysis is a data reduction statistical technique used to investigate underlying correlations in Likert-type variables (Hair et al., 1998). Debate amongst statisticians continues with regards to the adequate sample size permissible for undertaking reliable factor analysis and has resulted in several rules of thumb (Field, 2013). For example, Hatcher (1994) recommends sample sizes of at least 100 or 5 times the number of variables; and Creedy (2006) recommend a sample size to variable ratio of $2: 1$ through to 20:1. However, Field (2013) asserts that the most significant factor in determining the adequacy of factor solution is not only the absolute sample size but the absolute magnitude of the factor loadings as well. Hence, Guadagnoli and Velicer (1988) posit that if a factor has 4 or more loadings greater than 0.6 , then it is adequate for factor analysis regardless of the sample size. In addition, the Kaiser-Meyer-Olkin (KMO) (which is also a measure of sampling adequacy) compares the observed correlation coefficients to the partial correlation coefficients and can also be used to assess the adequacy of a sample size. A KMO value greater than 0.50 is acceptable to develop a successful factor analysis. A KMO of 0.650 suggests that the sample size was adequate to carry out the factor analysis. Similarly, The Bartlett's Test of Sphericity is also significant since the KMO is above 0.5 (Ghosh and Jintanapakanont, 2004). The Kaiser's criterion which considers factors with an eigenvalue greater than one was also adopted in extracting the factors. The factor extraction yielded five factors based on eigenvalues greater than 1.0 using the factor loading of 0.50 as the cut-off point. In order to obtain factor loadings that are easy to interpret, a varimax rotation was conducted to preserve the orthogonality of the principal components and to reduce the number of factors on which the variables have high loadings.

\section{Profile of Respondents}

Tavakol and Dennick, (2011) proffer that background knowledge about survey respondents helps to assess the reliability and integrity of the data received, and generates confidence and credibility in the results. Table 2 shows the survey respondents' demographic characteristics.

\section{$<$ Insert Table 2 about here $>$}

A high response rate of $85 \%$ was attained from the credit personnel. This compared to similar studies conducted in Ghana and illustrates the strict adherence to research strategies adopted in administering and retrieving the questionnaires. It also provides palpable evidence of respondents' interest in the subject matter. Experience is an important factor to consider in survey analysis as it could be a key cause of differing perceptions amongst the respondents. A greater share of all the respondents held a bachelor's degree (54\%) and postgraduate degree (38\%). This rich educational background coupled with the fact that about $81 \%$ of the respondents had more than 4 years practical experience in the Ghanaian mortgage market illustrates that the respondents were qualified enough to respond to the questionnaire. This professional competence and pragmatic experiencehelped to enhance the credibility of information gathered. 


\section{ANALYSIS AND DISCUSSION}

Table 3 presents the rotated factor loadings of the determinants of mortgage price affordability.

\section{$<$ Insert Table 3 about here $>$}

The first five variables yielded eigenvalues greater than one $(2.83,2,22,1.82$, $1.64,1.26)$. These were considered to be encouraging based upon the eigenvalueone criterion because the next eigenvalue of 0.83 (component six) cannot be considered as a 'near-miss.' Table 5 further illustrates that the first five components account for $75 \%$ of the total variance whereas the other $25 \%$ of the variance in mortgage interest rate pricing were explained by factors such administrative expenses, insurance and profit margin. This implies that according to the 'percentage of variance accounted for' criterion, the five components retained are appropriate. The factor analysis excluded two variables, namely: i) low income which is not considered at the loan pricing stage; and ii) cost of building the property which is outside the operation of the mortgage finance institutions.

\section{$<$ Insert Table 4 about here $>$}

Three variables (namely: i) base rate; ii) treasury bill rate; and iii) exchange rate) that were extracted according to the rotated factor pattern under component one explained $21.73 \%$ of the variance. A careful assessment of these 3 variables suggests the factors explain the phenomenon economic factors. Asabere et al., (2016) found a significant positive correlation between the size of the mortgage market and the level of gross national income per capita. A plausible explanation is that the accessibility of mortgage financing results in a more efficient financial system which tends to yield growth and development. Exchange rate originates from a persistent reduction in value of the domestic currency (Asabere et al., 2016). This affects the investor's capital especially if investment was made in domestic currency but returns paid in a foreign currency. Expected inflation/deflation is relevant for housing price decisions (Wong et al., 2005). Ceteris paribus, housing prices will rise when inflation is expected to upsurge. Follain (1982) demonstrats that at high interest rates, the households' liquidity problems dampen housing demands. Ghana is by far a consuming economy importing about $80 \%$ of all the construction inputs used in the housing industry (Arku, 2009). In addition, a weak national economy is vulnerable to external shocks such as crude oil prices (Adjasi, 2009). A shift in these externalities results in currency depreciation and inflation, making prices very elastic. Since its independence, Ghana has experienced double digit inflation: $17.9 \%$ between 1960 and 1970; 38.8\% between 1970 and 1979; 48.3\% between 1980 and 1989; $27.5 \%$ between 1990 and 1999; $18.4 \%$ between 2000 and 2009; and 13.77\% between 2010 and 2012 (Sowa and Kwaakye, 1993). The mix of these factors affects the way the central bank sets the base rate. Tsatsanoris and Zhu (2004)suggest that besides the marked difference between individual aspects of a national market, the most striking commonality is the dominance of inflation in the determination of real house prices. If financing decisions are more sensitive to the nominal yield curve than to real rates, one would expect housing demand and thus real house prices, to respond positively to changes in inflation and to 
expected changes in inflation. In addition, inflation may also be a proxy for the prevailing financing conditions, which impact upon the demand for real estate (Tsatsanoris and Zhu, 2004). According to Debelle (2004), high inflation and high nominal interest rates backload adversely impact on the repayment of the mortgage loan and increase the real value of repayment in the early part of the repayment period of the loan, thus dampening the demand for housing.

The second component which extracted loan-to-value and lack of long term fund accounts for $17.04 \%$ of the total variance extracted. The characteristics of these variables have been observed to largely explain financial factors. According to Tsatsanoris and Zhu (2004), the most essential parameters that determine the ability of banks to lend against real estate collateral are the existence and level of prudential ceilings on the LTV ratios in conjunction with a specific valuation technique employed. Methods that base lending decisions on a property's current market value tend to increase the sensitivity of credit availability to market conditions and could possibly create positive momentum in market demand. Conversely, valuations that are anchored to historical levels of prices tend to lag current market trends, thus exerting a counter repeated influence on credit availability.

The third component accounted for $13.98 \%$ of the variance and included the respective loading factors, namely, age of property (0.87) and property amount (0.61). Subsequently, this component was labeled property characteristics. The age of a property influences the market value of a property in two ways - i) economic depreciation; and ii) a vintage effect. According to Goodman and Thibodeau (1995) economic depreciation is defined as the decline in asset price due to aging while vintage effect occurs when some unmeasured housing characteristics (such as problems with structural timber, subsidence, leaks and plumbing problems) correlated with the building's age. New properties offer greater risk because of uncertain market acceptance while older properties are risky because of cost uncertainty (Archer et al., 1999). It could be concluded from the above that the market value of property tends to decrease with age.

The fourth component extracted property size (0.62) and property location (0.87) which together account for $12.57 \%$ of the variance and this component was labeled geographical factors. The housing market is not a single market but a series of overlapping submarkets differentiated by location, quality, age, dwelling type, tenure form and financing (Patel, 1994). Besides, the location of a particular property correlates with the likelihood of default by taking into account local economic conditions. Rauterkaus et al., (2010) opines that location efficiency for example can influence mortgage default risk. Location efficient homes refer to homes located in areas that reduce the likelihood of automobile ownership. Hence, if location efficiency is indeed a predictor for lower mortgage default, then it certainly provides an additional justification for government policy interventions to promote a more location efficient built environment. According to Archer et al., (2002), the characteristics of a collateral property may affect the likelihood of default even after underwriting adjustments are made in the loan terms. Most lenders argue that larger properties are more prone to default. Additionally, middle-quality apartments are less risky because during economic 
slumps they attract tenants descending while in a strong economy they attract tenants ascending.

The fifth component extracted the variables poor infrastructure (0.81) and underdeveloped mortgage market (0.85) which together account for $9.68 \%$ of the variance. The variables were observed to explain the phenomenon property developmental factors characteristics. Following the assessment by Mills and Hamilton (1994), it has been established that there is a direct relationship between the rental price and the real asset value. Sellon and Van Nahmen (1988) contend that the enhancement of the mortgage market through the capital market develops the efficiency of housing finance thereby increasing the liquidity of the mortgage market. Jaffe and Renaud (1996) added that a well-developed mortgage market provides enormous external benefit to the economy including capital market development, increased labour market mobility, construction sector employment, and the efficient allocation of real estate asset. An underdeveloped mortgage market and inadequate infrastructure (such as roads, electricity and water) render the mortgage market 'illiquid' and is characterised by huge risk factors that force financial institution to increase their interest rate.

\section{CONCLUSIONS}

A house is both an asset and a social good and hence, it is considered an issue of public policy. Understanding the determinants of housing affordability is therefore a significant first step towards monitoring the housing market trends within Ghana. This paper adopted a mixed method research approach to explore the mortgage price affordability factors for both low and middle income earners with particular focus on both banking and non-banking mortgage institutions. Using exploratory factor analysis, five components: i) economic; ii) financial; iii) property; iv) developmental; and v) geographic factors have been identified to be the underlining drivers influencing mortgage price affordability. The economic factors which had the highest variance were explained by three variables, namely: i) base rate; ii) treasury bill rate; and iii) exchange rate. These findings suggest that government must take pragmatic steps to implement policies aimed at improving the fundamentals of both macro and micro economic variables. Mortgage pricing affordability for low and middle income earners impacts upon the majority of the population; affordability ceases to be a purely economic problem but a significant socio-economic concern that requires the attention of government to develop programmes that enhance the disposable income of the working class. Comprehensive reforms should be carried out by the state and these may include: having an effective national policy on housing; devoting a portion of the oil revenue for provision of housing for the low and middle income; improving land registration and tenure system reform; and creating an enabling environment for the private sector to originate affordable housing through tax incentives (i.e. corporate tax exemptions, free duty on imported housing material).Failure to enhance mortgage price affordability will place enormous pressure on rental homes and engender social injustice for the majority of the Ghanaian population.

The findings of this research have expanded knowledge via establishing the determinants of mortgage price affordability. The results could be utilised to guide policy makers and practitioners within Ghana's fledgling mortgage market 
towards offering mitigating measures that appropriately target the low and middle income in the society. Even though the research information was gathered from Ghana, the results could equally be applied to other countries that exhibit similar market characteristics. Future research should however be targeted at considering models for the determination of affordable premiums and also explore potential factors of propensity to default premium payments. 


\section{REFERENCES}

Adjasi, C. (2009) Macroeconomic Uncertainty and Conditional Stock-price Volatility in Frontier African Markets: Evidence from Ghana, The Journal of Risk Finance, Vol. 10, No. 4, pp. 333-349. https://doi.org/10.1108/15265940910980641

ADB (African Development Bank) (2011) The Middle of the Pyramid: Dynamics of the Middle Class in Africa, Market Brief April 20, Available via: www.afdb.org/fileadmin/uploads/afdb/Documents/Publications.pdf [Accessed: August, 2016]

Ambrose, B. W., Buttimer Jr, R. J., and Capone, C. A. (1997) Pricing Mortgage Default and Foreclosure Delay, Journal of Money, Credit, and Banking, PP. 314-325. DOI: 10.2307/2953696

Arku, G. (2009) Housing Policy Changes in Ghana in the 1990s: Policy review. Housing Studies, Vol. 24, No. 2, pp. 261-272. DOI: http://dx.doi.org/10.1080/02673030902719763

Asabere, P. K., McGowan Jr, C. B. and Lee, S. M. (2016) A Study into the Links Between Mortgage Financing and Economic Development in Africa, International Journal of Housing Markets and Analysis, Vol. 9, No. 1, pp. 2DOI: 19. https://doi.org/10.1108/IJHMA-05-2014-0014

Asare, E. L. and Whitehead, C. (2006)Formal Mortgage Markets in Ghana: Nature and Implications.RICS Research Paper Series, Vol. 6, No.13. pp. 1221.

Archer, W. R., Elmer, P. J., Harrison, D. M. and Ling, D. C. (2002) Determinants of Multifamily Mortgage Default, Real Estate Economics, Vol. 30, No. 3, pp. 445-473. DOI: $10.1111 / 1080-8620 . t 01-1-00012$

Awuvafoge, S. A. (2013). Affordable housing in urban areas in Ghana: Issues and recommendations. Masters Thesis from Ball State University, Muncie Indiana.

https://cardinalscholar.bsu.edu/bitstream/handle/123456789/197225/Awuvaf ogeS_2013-2_BODY.pdf?sequence=1[Accessed: June, 2017]

Bank of Ghana (2007) The Housing Industry in Ghana: Prospects and Challenges, Policy Brief, Available via:

https://www.bog.gov.gh/statistics/publication/research-papers/policybriefs/397-the-housing-industry-in-ghana-prospects-and-challenges [Accessed: August 2016].

Barker, K. (2004) Review of Housing Supply. Delivering Security: Securing our Future Housing Needs, Final Report - Recommendations. Available via: http://webarchive.nationalarchives.gov.uk/20130129110402/http:/www.hmtreasury.gov.uk/d/barker_review_execsum_91.pdf[Accessed: August, 2016].

Battellino, R. (2010) Twenty Years of Economic Growth. Structural Change in the Australian Economy 1 Durable Goods and the Business Cycle 11 Economic Change in India 19 Ownership of Australian Equities and Corporate Bonds 25 Interpreting Market Responses to Economic Data 35, 103. Available via: http://wwwho.rba.gov.au/publications/bulletin/2010/sep/pdf/bu-0910.pdf\#page=105 [Accessed: June, 2017].

Boamah N.A. (2009) Secondary Mortgage Market (SMM): Is it Right for Financing Housing, Journal of Science and Technology, Vol. 29, No1. pp. 17-27. DOI: http://dx.doi.org/10.4314/just.v29i1.46425 
Boamah, N.A. (2003). "The Impact of Liberalization on Residential Property Financing in Ghana",Unpublished MPhil Thesis, Department of Land Economy, and University of Cambridge-UK.

Bonsu, C. (2007) Challenges of and Opportunities for Developing Mortgage Market, Available via:www.cenbank.org/fss/tue/bsp/Mortgage posted 19th June,2007 [Accessed: June, 2017].

Bramley, G. (2012) Affordability, Poverty and Housing Need: Triangulating Measures and Standards, Journal of Housing and the Built Environment, Vol. 27, No. 2, pp. 133-151. DOI: 10.1007/s10901-011-9255-4

Brennan, M. J. and Schwartz, E. S. (1985) Determinants of GNMA Mortgage Prices, Real Estate Economics, Vol. 13, No. 3, pp. 209-228. DOI: $10.1111 / 1540-6229.00351$

Budget Statement (2008) Ministry of Finance Highlights on Budget Statement. Available via: http://www.mofep.gov.gh/sites/default/files/budget/2008_Budget_Highlight.p df[Accessed: June, 2017].

Buser, S. A. andHendershott, P. H. (1985) The Pricing of Default-Free Mortgages. NBER Working Paper Series, 1408. Available via: https://poseidon01.ssrn.com/delivery.php?ID=9940201230000971090930790 $\underline{220681100100840450670600950281100310350131160960450700670560300}$ 270000211170910720420330790900940040211150220901140060050751231 $03019027074108019067108023006008105093027 \& \mathrm{EXT}=\mathrm{pdf} \quad$ [Accessed: June, 2017].

Calomiris, C. W., Kahn, C. M. andLonghofer, S. D. (1994) Housing-finance Intervention and Private Incentives: Helping Minorities and the Poor, Journal of Money, Credit and Banking, Vol. 26, No. 3, pp. 634674.DOI: $10.2307 / 2077996$

Centre for Affordable Housing Finance (CAHF) (2012) Access to Formal

Housing in Ghana. A review of some of Africa's housing finance markets.2012 Yearbook, pp. 69-71

Chatterjee, L.R. (1982) Effective Targeting for Basic Shelter Provision, Economic Geography, Vol. 58 No. 1, pp. 62-74. DOI: 10.2307/143620

Creedy, G. (2006)Risk Factors Leading to Cost Overrun in the Delivery of Highway Construction Projects. A PhD Dissertation from Queensland University of Technology. Available via: https://eprints.qut.edu.au/16399/1/Garry Creedy Thesis.pdf [Accessed: June, 2017].

CSIR (2000) Human Settlement Planning and Design, Vol. 1 Available via: https://www.csir.co.za/sites/default/files/Documents/Red_BookVol2.pdf:

Accessed: June, 2017

Cunningham, D. F. and Hendershott, P.H. 1984) Pricing FHA Mortgage Default Insurance. No. 1382. National Bureau of Economic Research, Inc, 1984. Available via: https://www.researchgate.net/profile/Donald Cunningham/publication/5188 789 Pricing FHA Mortgage Default Insurance/links/02e7e53874ce5134730 00000.pdf [Accessed: June, 2017].

Cunningham, D. F. and Capone, C. A. (1990) The Relative Termination Experience of Adjustable to Fixed-Rate Mortgages. The Journal of Finance, Vol. $\quad 45$, No. $\quad 5$, pp. 1687-1703. DOI: $10.1111 /$ j.15406261.1990.tb03737.x 
Debelle, G. (2004) Macroeconomic Implications of Rising Household Debt (No. 153). Bank for International Settlements. Available via: https://papers.ssrn.com/sol3/papers.cfm?abstract_id=786385 $\quad$ [Accessed: June, 2017].

Donkor-Hyiaman, K.A. (2013) Rethinking Ghana's Housing Financing Challenge: A Paradigm Shift from the Traditional Mortgage Financing Approach. Unpublished MPhil Dissertation submitted in Partial Fulfillment of an MPhil Degree in Planning Growth and Regeneration.Department of Land Economy. University of Cambridge, United Kingdom

Duan, M. (2011) Investigation on Housing Affordability in Lanzhou, Northwest China, International Journal of Housing Markets and Analysis, Vol. 4, No. 2, pp. 180-190. DOI: https://doi.org/10.1108/17538271111137958

Dunn, K. B. and McConnell, J. (1981) A Comparison of Alternative Models for Pricing GNMA Mortgage-Backed Securities. The Journal of Finance, Vol. 36, No. 2, pp. 471-484. DOI: 10.1111/j.1540-6261.1981.tb00463.x

Field, A. (2013) Discovering Statistics using IBM SPSS Statistics. Sage. ISBN:9781446249178

Follain, J. R. (1982) Does Inflation Affect Real Behavior: The Case of Housing, Southern Economic Journal, pp. 570-582. DOI: 10.2307/1058651

Gabriel, M., Jacobs, K., Arthurson, K., Burke, T. and Yates, J. (2005) Conceptualising and Measuring the Housing Affordability Problem. Available via: http://www.ahuri.edu.au/_data/assets/pdf_file/0020/2693/NRV3_Research_ Paper_1.pdf[Accessed; June, 2017].

Ganiyu, B.O, Fapohunda, J.A. Haldenwang, R. (2017) Sustainable housing financing model to reduce South Africa housing deficit. International Journal of Housing Markets and Analysis, Vol. 10, No. 3, pp. 410430,https://doi.org/10.1108/IJHMA-07-2016-0051

Ghana Statistical Service (2007) Pattern and Trends of Poverty in Ghana: 19912006. Available via: https://s3.amazonaws.com/ndpcstatic/CACHES/NEWS/2015/07/22//GGLSS5+Pattern_Trends+Poverty+in+ GH.pdf [Accessed: July, 2017].

Ghosh, S. and Jintanapakanont, J. (2004) Identifying and Assessing the Critical Risk Factors in an Underground Rail Project in Thailand: A Factor Analysis Approach, International Journal of Project Management, Vol. 22, No. 8, pp. 633-643. DOI: https://doi.org/10.1016/j.ijproman.2004.05.004

Goodman, A. C. and Thibodeau, T. G. (1995) Age-related Heteroskedasticity in Hedonic House Price Equations, Journal of Housing Research, Vol. 6, No. 1, p. 25.DOI: $10.1111 / 1540-6229.00742$

Guadagnoli, E. and Velicer, W. F. (1988) Relation to Sample Size to the Stability of Component Patterns, Psychological Bulletin, Vol. 103, No. 2, pp. 265.DOI: http://dx.doi.org/10.1037/0033-2909.103.2.265

Gyourko, J. and Linneman, P. (1993) The Affordability of the American Dream: an Examination of the Last 30 Years, Journal of Housing Research, Vol. 4 No. 1, pp. 39-72. DOI: http://www.jstor.org/stable/24832754

Hair, J.F., Anderson, R.E., Tatham, R.L. and Black, W.C. (1998) Multivariate Data Analysis, $5^{\text {th }}$ Ed. Prentice Hall, New Jersey ISBN: 0139133100

Hargreaves, B. (2003) Home Ownership - an Increasingly Elusive Goal, Paper Presented at Pacific Rim Real Estate Society (PRRES) Conference, Brisbane, 19-22 January. Available via: 
http://www.prres.net/Papers/Hargreaves_Home_Ownership_An_Increasingl y_Elusive_Goal.pdf[Accessed: July, 2017].

Hatcher, L. (1994) A Step-by-step Approach to Using the SAS ® System for Factor Analysis and Structural Equation Modeling. Cary, NC: SAS Institute Inc. ISBN: 9781555446437

HFC Bank (Ghana) Limited (2007) Prospectus Supplement, HFC, Accra, Ghana. Available via: http://www.gipc.org.gh/Documents/Property.pdfh (Accessed on 20th January, 2013) [Accessed: July, 2017].

Huchzermeyer,M. (2001) Housing for the Poor? Negotiated Housing Policy in South Africa. Habitat International, Vol. 25, pp. 303-331.

Jaffee, D. and Renaud, B. (1997) Strategies to Develop Mortgage Markets in Transition Economies. Financial Sector Reform and Privatization in Transition Economies. Available via: https://ssrn.com/abstract $=623883$ [Accessed: July, 2017].

Kau, J. B., Keenan, D. C. and Kim, T. (1993) Transaction Costs, Suboptimal Termination and Default Probabilities, Real Estate Economics, Vol. 21, No. 3, pp. 247-263. DOI: 10.1111/1540-6229.00610

Kish, L. (1965). Sampling organizations and groups of unequal sizes. American sociological review, 564-572. http://www.jstor.org/stable/2091346

Lea, M. J. (2000) Prerequisitesfor a Successful Secondary Mortgage Market: The Role of the 18 Primary Market, Housing Finance International,Vol. 15, No. 2, p. 26-41. Available via: http://www.housingfinance.org/uploads/Publicationsmanager/0012 Mex.pdf [Accessed: July, 2017].

Maclennan, D. and Williams, R. (1990) Affordable Housing in Britain and America. Joseph Rowntree Foundation, York.ISBN 1872470092, 9781872470092

Mc Donald and Thornton, (2008)A Primer on the Mortgage Market and Mortgage Finance, Federal Reserve Bank of St. Louis Review Available via: https://research.stlouisfed.org/publications/review/2008/01/01/a-primer-onthe-mortgage-market-and-mortgage-finance/[Accessed: July, 2017].

Mills, E. S. and Hamilton, B. W. (1994) Urban Economics. Scott, Foresman, Glenview, IL. ISBN: 9780673468673

Milligan, V., Phibbs, P., Fagen, K. and Gurran, N. (2004) A Practical Framework for Expanding Affordable Housing Services in Australia: Learning from Experience', AHURI Final Report, AHURI Sydney Research, Sydney.

Mitlin, D. (2008) Editorial: Finance and Shelter Improvements. Environment and Urbanization, Vol. 20, No. 1, pp. 3-12.DOI: 10.1177/0956247808089145

Nwuba, C. C., Kalu, I. U. andUmeh, J. A. (2015) Determinants of Homeownership Affordability in Nigeria's Urban Housing Markets. International Journal of Housing Markets and Analysis, Vol. 8, No. 2, pp. 189-206. DOI: https://doi.org/10.1108/IJHMA-06-2014-0020

Owusu-Manu, D. , Pärn, E.A. Donkor-Hyiaman, K. Edwards, D.J.. Blackhurst, K.. (2016) "The relative importance of mortgage pricing determinants in mortgage affordability in Ghana: An ex post attribution", Journal of Engineering, Design and Technology, Vol. 14 Issue: 3, pp.563-579, https:// doi.org/10.1108/JEDT-06-2014-0040

Paris, C. (2007) International Perspectives on Planning and Affordable Housing, Housing Studies, Vol. 22, No. 1, pp. 1-9. DOI: http://dx.doi.org/10.1080/02673030601024531 
Patel, K. (1994) Lessons from the FOX Residential Property Futures and Mortgage Interest Rate Futures Market, Housing Policy Debate, Vol. 5, No. 3, pp. 343-360.DOI: http://dx.doi.org/10.1080/10511482.1994.9521168

Pennington-Cross, A. and Ho, G. (2010) The Termination of Subprime Hybrid and Fixed-Rate Mortgages. Real Estate Economics, Vol. 38, No. 3, pp. 399426. DOI: $10.1111 / \mathrm{j} .1540-6229.2010 .00271 . \mathrm{x}$

Poon, J. and Garratt, D. (2012) Evaluating UK Housing Policies to Tackle Housing Affordability, International Journal of Housing Markets and Analysis, Vol. $5, \quad$ No. 3, pp. 253-271. DOI: https://doi.org/10.1108/17538271211243599

Posey, L. L. andYavas, A. (2001) Adjustable and Fixed Rate Mortgages as a Screening Mechanism for Default Risk, Journal of Urban Economics, Vol. 49, No. 1, pp. 54-79.DOI: https://doi.org/10.1006/juec.2000.2182

Rauterkus, S., Thrall, G. andHangen, E. (2010) Location Efficiency and Mortgage Default, Journal of Sustainable Real Estate, Vol. 2, No. 1, pp. 117-141.DOI: https://doi.org/10.5555/jsre.2.1.w00u2v11w56118p7

Saunders, A., \& Allen, L. (2010). Credit risk management in and out of the financial crisis: new approaches to value at risk and other paradigms (Vol. 528). John Wiley \& Sons. ISBN 978-0-470-47834-9F

Sellon, G.H and Van Nahmen, D.H. (1988)The securitization of housing finance, economic review. Federal Reserve Bank of Kansas City, pp.3-20

Solomon-Ayeh, K. A. (1994) Studies of Strengths of Stabilized Laterite Blocks and Rendering Mortars, Building Research and Information, Vol. 22, No. 3, pp. 159-166.DOI: http://dx.doi.org/10.1080/09613219408727372

Sowa, N. andKwaakye, J. (1993) Inflationary Trends and Control in Ghana. African Economic Research Consortium. Available via: https://opendocs.ids.ac.uk/opendocs/bitstream/handle/123456789/2080/No\%2 022.pdf?sequence=1 [Accessed: July, 2017].

South Africa National Department of Housing, (2001)The South African Housing Policy: Operationalizing the Right to Adequate Housing. Thematic Committee 6 - 8 June 2001

Stone, M. E. (2006) What is Housing Affordability? The Case for the Residual Income Approach, Housing Policy Debate, Vol. 17, No. 1, pp151-184. DOI: http://dx.doi.org/10.1080/10511482.2006.9521564

Tarver, J.D. (1994) Urbanization in Africa. A Handbook (ed).Westport: Preager Publishers.ISBN: 0313277605

Tavakol, M. and Dennick, R. (2011) Making Sense of Cronbach's Alpha. International Journal of Medical Education, Vol. 2, pp. 53-55. DOI: $10.5116 /$ ijme.4dfb.8dfd

Turner, J. F. C. (1967) Barriers and Channels for Housing Development in Modernizing Countries, Journal of the American Institute of Planners, Vol. 32, pp. 167-181 DOI: http://dx.doi.org/10.1080/01944366708977912

Tsatsaronis, K. and Zhu, H. (2004) What Drives Housing Price Dynamics: CrossCountry Evidence. BIS Quarterly Review, March.Available via: http://www.bis.org/publ/qtrpdf/r qt0403f.pdf[Accessed: July, 2017].

UNCHS (1996) AnUrbanising World: Global Report on Human Ssettlements 1996, Oxford University Press. ISBN: 0198233469

UN-Habitat (2009) Housing Finance Systems in South Africa. The Human Settlements Finance Systems Series, UN-Habitat, Nairobi, Kenya ISBN: 978-92-1-132007-7 
UNFPA (2007) State of the World Population -Unleashing the Potential of Urban Growth. Available via: www.unfpa.org/swp/2007/presskit/pdf/sowp2007[Accessed: July, 2017].

Wolswijk, G. (2005) On Some Fiscal Effects on Mortgage Debt Growth in the EU,European Central Bank, Working Paper Series, No. 526. Available via: https://www.ecb.europa.eu/pub/pdf/scpwps/ecbwp526.pdf?d36e8e54e3c73885 9faa408689636e7c [Accessed: July, 2017].

Wong, J. T. Y., Hui, E. C., Seabrooke, W., \& Raftery, J. (2005). A study of the Hong Kong property market: housing price expectations. Construction Management and Economics, 23(7),

757 765.http://dx.doi.org/10.1080/01446190500127260

Yartey, T. (2012) Mortgage is New. Available via: www.thebftonline.com[Accessed: July, 2017]. 
Table 1 - Mortgage Originations by HFC, 1992-2007gagors (US\$) Annual

\begin{tabular}{ccccc}
\hline Year & Mortgagor & $\begin{array}{c}\text { Annual } \\
\text { Change \% }\end{array}$ & $\begin{array}{c}\text { Mortgage } \\
\text { ('000 US } \\
\text { Dollars) }\end{array}$ & $\begin{array}{c}\text { Annual } \\
\text { Change }\end{array}$ \\
\hline 1992 & 163 & & 1,900 & \\
1993 & 272 & 66.87 & 3,800 & 100 \\
1994 & 824 & 202.94 & 4,200 & 10.53 \\
1995 & 417 & $(49.39)$ & 2,500 & $(40.48)$ \\
1996 & 411 & $(1.45)$ & 4,300 & 72 \\
1997 & 401 & $(2.43)$ & 3,000 & $(30.23)$ \\
1998 & 351 & $(12.47)$ & 7,000 & 133.33 \\
1999 & 270 & $(23.08)$ & 6,900 & $(1.43)$ \\
2000 & 230 & $(14.81)$ & 5,700 & $(17.39)$ \\
2001 & 300 & 30.44 & 4,900 & $(14.04)$ \\
2002 & 106 & $(64.67)$ & 2,653 & $(45.85)$ \\
2003 & 85 & $(19.81)$ & 2,244 & $(15.43)$ \\
2004 & 82 & $(3.53)$ & 1,845 & $(17.75)$ \\
2005 & 83 & 0.01 & 2,019 & 9.42 \\
2006 & 223 & 168.68 & 5,907 & 192.50 \\
2007 & 235 & 5.38 & 4,571 & $(22.6)$ \\
\hline Total & $\mathbf{4 , 4 5 3}$ & & $\mathbf{6 3 , 4 4 2}$ & \\
\hline
\end{tabular}

Source: HFC Bank (2007) cited from Boamah, 2009. 
Table 2 - Characteristics of Respondents

\begin{tabular}{lcccccc}
\hline \multirow{2}{*}{ Description } & \multicolumn{3}{c}{ Experience } & \multicolumn{3}{c}{ Education } \\
\cline { 2 - 7 } Credit Personnel & $0-4$ & $5-8$ & $>8$ & Diploma & Bachelor & Post-Graduate \\
& 4 & 7 & 9 & 2 & 11 & 7 \\
\hline
\end{tabular}


Table 3 - Extraction Method: Principal Component Analysis.

\begin{tabular}{|c|c|c|c|c|c|c|c|c|c|}
\hline \multirow{2}{*}{ Components } & \multicolumn{3}{|c|}{ Initial Eigenvalues } & \multicolumn{3}{|c|}{$\begin{array}{c}\text { Extraction Sums of Squared } \\
\text { Loadings }\end{array}$} & \multicolumn{3}{|c|}{$\begin{array}{c}\text { Rotation Sums of Squared } \\
\text { Loadings }\end{array}$} \\
\hline & Total & $\begin{array}{c}\% \text { of } \\
\text { Variance }\end{array}$ & $\underset{\%}{\text { Cumulative }}$ & Total & $\begin{array}{c}\% \text { of } \\
\text { Variance }\end{array}$ & $\underset{\%}{\text { Cumulative }}$ & Total & $\begin{array}{c}\% \text { of } \\
\text { Variance }\end{array}$ & $\underset{\%}{\text { Cumulative }}$ \\
\hline 1 & 2.83 & 21.73 & 21.73 & 2.83 & 21.73 & 21.73 & 2.56 & 19.67 & 19.67 \\
\hline 2 & 2.22 & 17.04 & 38.77 & 2.22 & 17.04 & 38.77 & 2.03 & 15.62 & 35.30 \\
\hline 3 & 1.82 & 13.98 & 52.75 & 1.82 & 13.98 & 52.75 & 1.98 & 15.22 & 50.52 \\
\hline 4 & 1.64 & 12.57 & 65.32 & 1.64 & 12.57 & 65.32 & 1.77 & 13.60 & 64.12 \\
\hline 5 & 1.26 & 9.68 & 74.99 & 1.26 & 9.68 & 74.99 & 1.41 & 10.88 & 74.99 \\
\hline 6 & .83 & 6.41 & 81.41 & & & & & & \\
\hline 7 & .72 & 5.53 & 86.93 & & & & & & \\
\hline 8 & .59 & 4.53 & 91.46 & & & & & & \\
\hline 9 & .46 & 3.55 & 95.01 & & & & & & \\
\hline 10 & .25 & 1.91 & 96.92 & & & & & & \\
\hline 11 & .22 & 1.67 & 98.59 & & & & & & \\
\hline 12 & .14 & 1.08 & 99.67 & & & & & & \\
\hline 13 & .04 & 0.33 & 100.00 & & & & & & \\
\hline
\end{tabular}


Table 4- Components Explained

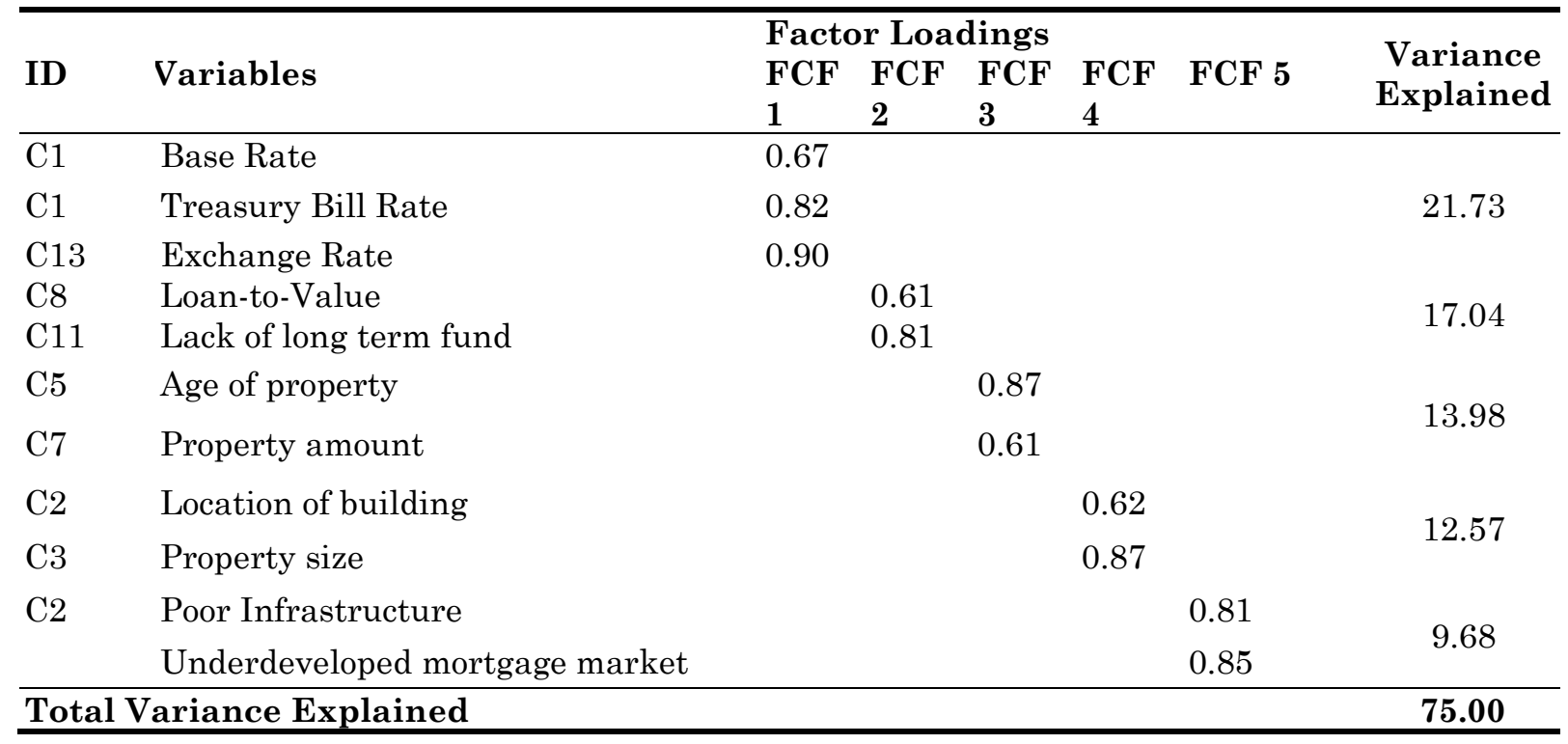


Figure 1 - Inflation Rate of Ghana from January - October, 2017 GHANA INFLATION RATE

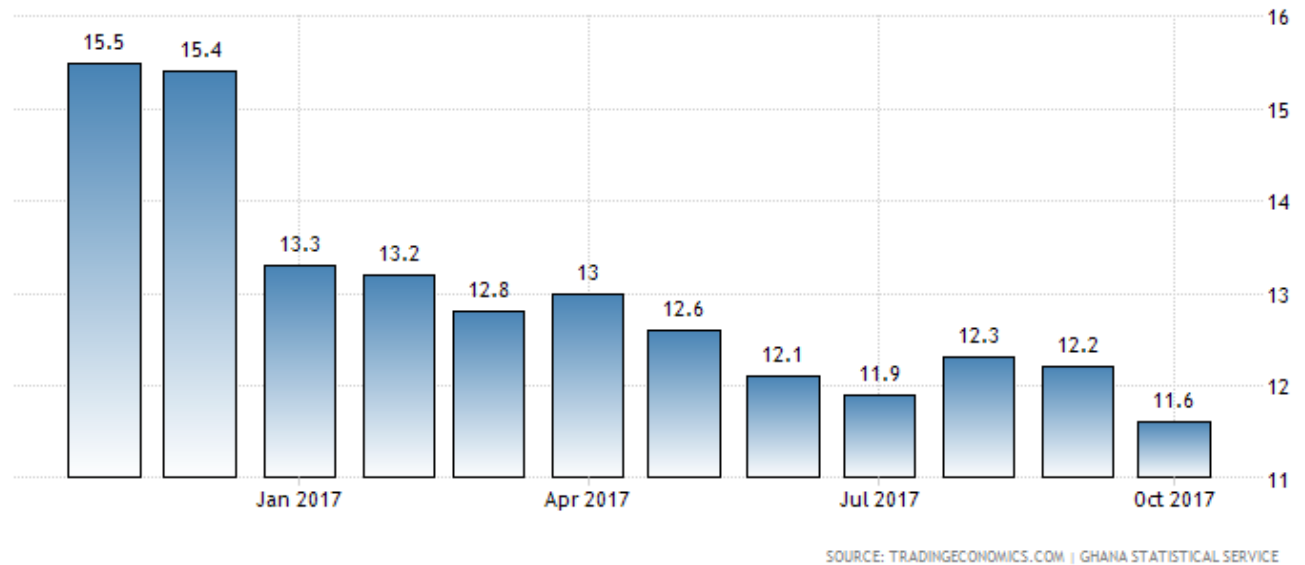

Source: https://tradingeconomics.com/ghana/inflation-cpi 
Figure 2 - Interest Rate of Ghana from April 2016 - October, 2017

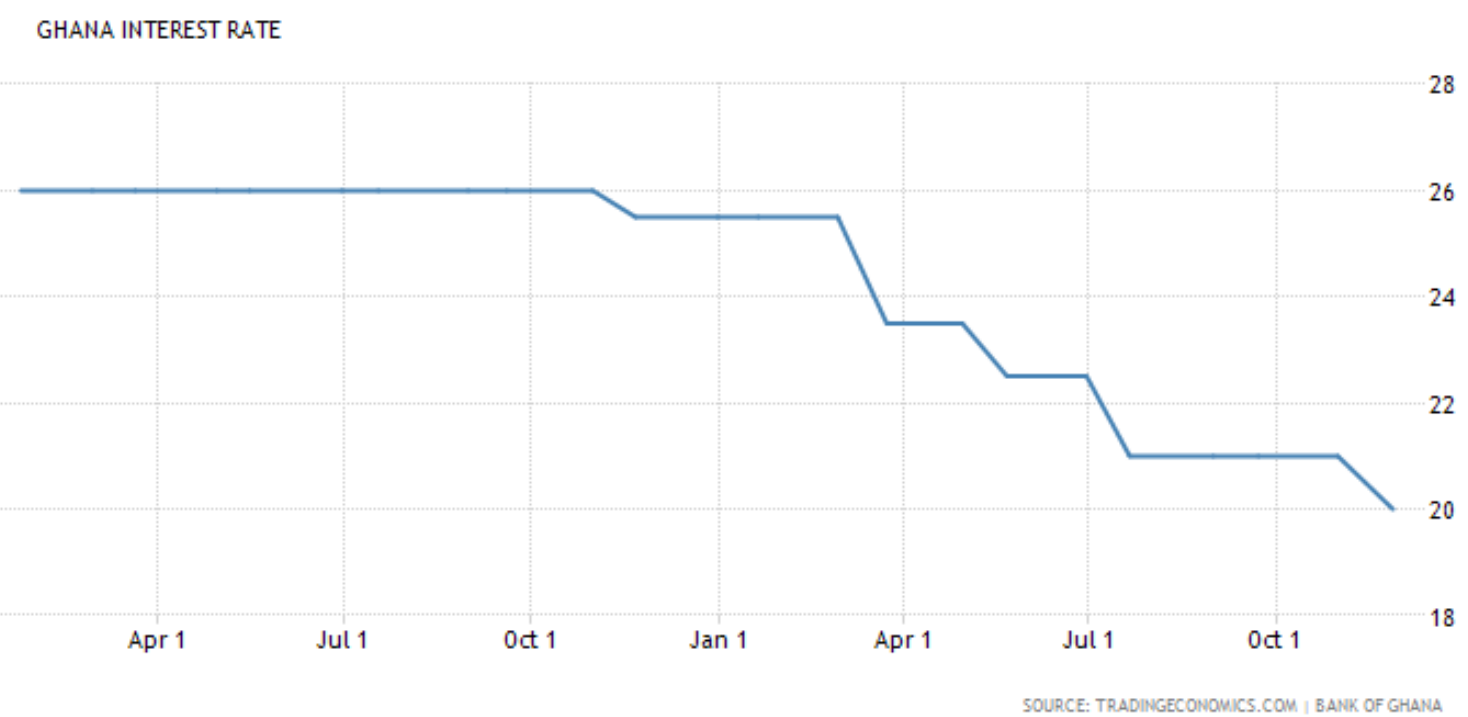

Source: https://tradingeconomics.com/ghana/inflation-cpi 